\title{
Cellular Localization of Ephrin-A2, Ephrin-A5, and Other Functional Guidance Cues Underlies Retinotopic Development across Species
}

\author{
Roger W. Davenport, ${ }^{1}$ Edda Thies, ${ }^{1}$ Renping Zhou, ${ }^{2}$ and Phillip G. Nelson ${ }^{1}$ \\ ${ }^{1}$ Laboratory of Developmental Neurobiology, National Institute of Child Health and Human Development, National \\ Institutes of Health, Bethesda, Maryland 20892, and 2Laboratory for Cancer Research, College of Pharmacy, Rutgers \\ University, Piscataway, New Jersey 08855
}

\begin{abstract}
Avian retinotectal and rodent retinocollicular systems are general model systems used to examine developmental processes that underpin topographically organized neuronal circuits. The two systems rely on guidance components to establish their precise retinotopic maps, but many cellular events differ during their development. For example, compared with the chick, a generally less restricted outgrowth pattern is observed when retinae innervate their targets in rodents. Cellular or molecular distributions of guidance components may account for such differences in retinotopic development across species. Candidate repellent molecules, such as ephrin-A2 and ephrin-A5, have been cloned in both chick and rodents; however, it has not yet been shown in rodents that living cells express sufficient amounts of any repellent components to deter outgrowth. We used a coculture assay that gives cellular resolution of retinotarget interactions and demonstrate that living, caudal superior
\end{abstract}

colliculus cells selectively prevent extension of axons from temporal regions of the retinae. Time-lapse video microscopy revealed the cellular localization of permissive and repulsive guidance components in rodents, which differed from that in chick. To analyze the potential molecular basis for these differences, we investigated the function and localization of ephrin-A2 and -A5. Cells transfected with ephrin-A2 and -A5 selectively repelled retinal axons. Ephrin-A2 and -A5 RNA expression patterns differed across cell populations and between species, suggesting molecular mechanisms and key cellular interactions that may underlie fundamental differences in the development of retinotectal and retinocollicular maps.

Key words: retinocollicular; topographic projection; growth cone; neuronal development; filopodia; repulsion; retraction; retinotopic; retinotectal; Eph receptor tyrosine kinase; ephrin; guidance cues
The visual system has served widely as a model system for the early neuronal pathfinding events, which result in the stereotyped circuitry necessary for a functional nervous system. In particular, development of the retinotectal and retinocollicular projections has been studied in fish, amphibia, birds, and rodents (Stahl et al., 1990; Stirling, 1991; Fraser, 1992; Mey and Thanos, 1992; Roskies et al., 1995). In each, optic fibers are distributed systematically across their targets, forming a topographic map such that the distribution of retinal ganglion cell (RGC) terminals reflects their site of origin in the retinae (for review, see Fraser and Hunt, 1980; Udin and Fawcett, 1988; Constantine-Paton et al., 1990; TessierLavigne and Goodman, 1996). Retinotopic order arises during development and results, in part, from advancing neuronal growth cones responding to key guidance cues distributed across the cells that form their targets. Two molecules, ephrin-A2 and ephrin-A5, are relevant to the sorting of optic fibers across the rostrocaudal dimension of retinal targets. They are both expressed in an increasing rostrocaudal gradient across the chick

\footnotetext{
Received Sept. 5, 1997; revised Nov. 4, 1997; accepted Nov. 6, 1997.

This research was performed in part while R.W.D. held a National Research Council-National Institute of Child Health and Human Development/National Institutes of Health Research Associateship. We especially thank Pan-Pan Gao for her laborious transfection and subsequent generous gift of NIH-3T3 cells. We thank Elaine Neale and Carol Ann Mason for their gift of antibodies; Doug Frost for helpful discussions; Steve Coon for immeasurable technical help with the analysis of RNA; and Eric Snyder, Diane Snow, and Jacques Tham for helpful comments on this manuscript.

Correspondence should be addressed to Dr. Roger W. Davenport, Laboratory of Developmental Neurobiology, National Institutes of Health, 49 Convent Drive, MSC4480, Building 49, Room 5A38, Bethesda, MD 20892-4480.

Copyright (C) 1998 Society for Neuroscience $0270-6474 / 98 / 180975-12 \$ 05.00 / 0$
}

tecta and the rodent midbrain (Cheng et al., 1995; Drescher et al., 1995; Donoghue et al., 1996; Zhang et al., 1996). In the chick, the ability of ephrin-A2 and -A5 to repel RGC fibers has been demonstrated, using both cell membrane fraction assays and the transfection of tectal cells (Drescher et al., 1995; Nakamoto et al., 1996; Monschau et al., 1997). However, little evidence has been provided for ephrin-A2 and -A5 function in the mouse, in which knock-outs and other key genetic experiments will take place, and considerable differences exist between avian and rodent retinotopic development (Vanegas, 1984; Simon and O'Leary, 1990, 1991; Roskies et al., 1995). For example, the extension of optic fibers across their targets differs both in the laminae in which they extend and also in the overall length of their extension before the rudimentary map begins to form [compare chick from studies by Crossland et al. (1974, 1975) and Vanselow et al. (1989) with rodent from studies by Sachs and Schneider (1984), Stein (1984), Edwards et al. (1986a,b), and Frost et al. (1986)]. Moreover, in rodents, the contact-mediated repulsion observed in culture is not reflected by retinal outgrowth patterns in vivo (Godement et al., 1984; Simon and O'Leary, 1992), suggesting that living superior colliculus (SC) cells must be examined for their vital ability to repel axons. Neither previous cell culture assays nor the molecular patterns of ephrin-A2 and -A5 have suggested underlying mechanisms that may account for the differences that exist during development of the avian and rodent retinotopic maps. Importantly, a single parallel functional and molecular analysis has not been made with cellular resolution in any system.

We undertook a comprehensive analysis of the different growth cone behaviors that are revealed when RGCs encounter individ- 
ual target cells. The functional cues in the mouse retinocollicular system that we currently present differ from those previously reported in the chick (Davenport et al., 1996). The cellular and molecular expression of the repellent cues ephrin-A2 and -A5, therefore, were examined in both systems. Together, the characteristic growth cone behavior and the distinct expression patterns of ephrin-A2 and -A5 revealed in the present investigation can account for fundamental differences in the development of retinotopic maps among vertebrates.

\section{MATERIALS AND METHODS}

Chamber preparation. We used a three-compartment chamber designed by combining unique features of Campenot chambers (Campenot, 1977) and Klostermann chambers (Klostermann and Bonhoeffer, 1996). This chamber allowed elongating RGC axons to contact SC cells in a consistent and predictable manner by separating retinal explants and SC cell cultures in an otherwise uniform culture dish (Fig. $1 A$ ). A Teflon ring with an outer diameter of $2 \mathrm{~cm}$ was cut with Teflon guides. A small amount of grease (high vacuum; Dow Corning, Midland, MI) was spread at the edge of glass coverslips (\#1) in alignment with the Teflon guides to allow the coverslips to remain attached to the Teflon insert and slide vertically along the guides. When coverslip barriers were positioned at their lowest extreme, three isolated compartments were created so that different cells could be placed in each. After construction, chambers were autoclaved and ready for use. Dissociated SC cells were placed in the center compartment; subsequently, retinal explants from chick, mouse, or rat were positioned in each side. Coverslip barriers were used to delimit areas of the culture dish during cell preparation and were removed before axonal extension.

Coculture preparation. Cultures were prepared either on plastic dishes (35 mm, NUNC; PGC Scientific, Gaithersburg, MD) or on glass inserts (\#1; Carolina Supply, Burlington, NC) placed under a hole $(2.2 \mathrm{~cm}$ ) cut through the center of the culture dish and coated with laminin $(20 \mu \mathrm{g} / \mathrm{ml}$; Life Technologies, Gaithersburg, MD) overnight. Plastic dishes were scratched with a microcomb made from insect pins (Fields et al., 1990). The Teflon and glass insert was positioned approximately in the center of each dish, and glass barriers were lowered until they contacted the bottom of the dish.

SC were removed from embryonic mouse [embryonic days 13-15 (E13-E15)] or rat (E16-E18) and separated into three sections (Fig. 1A). The middle section was discarded, while the rostral and caudal sections were dissociated mechanically in calcium- and magnesium-free Gey's buffered salt solution (Life Technologies) and subsequently concentrated by centrifugation and resuspended to a density of $4.5 \times 10^{6}$ cells $/ \mathrm{ml}$ in DMEM/F12 medium (Life Technologies) with an additional 10\% fetal calf serum (Life Technologies) and $0.4 \%$ methylcellulose (Dow Chemical, Midland, MI). Cultures used for immunostaining did not include methylcellulose. Dissociated cells $(50 \mu \mathrm{l})$ from either rostral or caudal SC were dispersed into the center compartment and allowed to settle in the incubator $\left(37^{\circ} \mathrm{C}, 10 \% \mathrm{CO}_{2}\right)$ for $3 \mathrm{hr}$.

Retinal explants were prepared according to previously established methods (Halfter et al., 1983; Wizenmann et al., 1993; Baier and Klostermann, 1994). Briefly, retinae were removed from embryonic chickens (White Leghorn, E5-E9), mouse (E13-E15), or rat (E16-E18), flat-mounted onto nitrocellulose filters (Sartorius, Bohemia, NY), and subsequently cut into strips $(0.25 \mathrm{~mm}$ in width for rodent retinae; 0.40 $\mathrm{mm}$ for chick) along the dorsoventral axis to provide retinal explants specifically from either nasal or temporal retinae (indicated by vertical lines in Fig. 1A). Only retinal strips from the peripheral one-third of the retinae were used for experimentation; strips from the central one-third were discarded. Then retinal strips were positioned in the side compartment $\geq 1 \mathrm{~mm}$ from and parallel to the coverslip barrier $(\sim 1 \mathrm{~mm}$ for rodent retinae; $2-3 \mathrm{~mm}$ for chick retinae). Subsequently, $\sim 4 \mathrm{ml}$ of medium was added to ensure that the medium topped the chamber, and coverslip barriers were raised or removed. Dishes were maintained in a humidified incubator at $37^{\circ} \mathrm{C}, 10 \% \mathrm{CO}_{2}$. Cultures were used after $1-5 \mathrm{~d}$.

Video microscopy. Cultures to be used for time-lapse microscopy were transported from the incubator to the stage of an inverted microscope (Nikon Diaphot, Tokyo, Japan) previously warmed to $37^{\circ} \mathrm{C}$. Approximately $10 \% \mathrm{CO}_{2}$ was blown continuously across the dish to maintain medium $\mathrm{pH}$ at $\approx 7.3$. Phase-contrast microscopy and Hoffmann modulation contrast microscopy were performed with $20 \times$ or $40 \times$ objectives and matched long-working-distance condensers. Images were collected via a
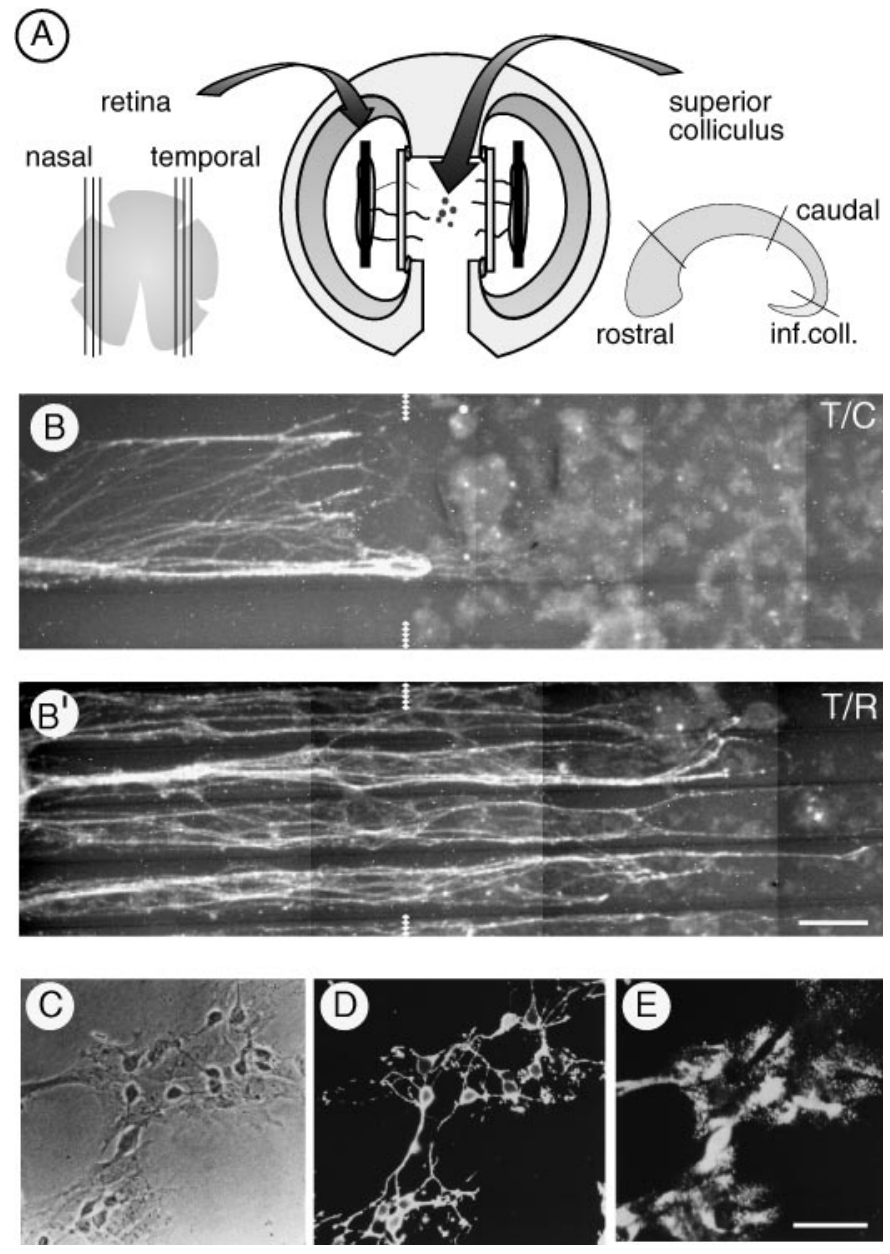

Figure 1. The coculture preparation, general outgrowth pattern, and immunocytochemical identification of cultured cells are presented. $A$, Explants obtained from temporal and nasal regions of the retinae and placed into the side compartment of a three-compartment chamber extend axons toward the center compartment, where dissociated cells from different regions of the mouse SC are cultured. $B$, Temporal RGC axons stop at the border and become highly fasciculated when they encounter cells from caudal regions of the SC. $B^{\prime}$, In the same experiment temporal axons extend well across areas with dissociated rostral SC cells. The boundary of SC cells is aligned and indicated by the jagged lines. Chick RGC axons are stained selectively with an antibody (8D9) against chick $\mathrm{Ng}$-CAM. Scale bar, $0.5 \mathrm{~mm}$. $C$, A phase-contrast micrograph displays a representative field of dissociated SC cells after $3.5 \mathrm{~d}$ in culture. Already by $2 \mathrm{~d}$ in culture the neurons stain positively with a number of neuronalspecific antibodies such as tetanus toxin/fragment $C(D)$, and glia stain positively with non-neuronal radial glial antibodies such as RC2 $(E)$. Scale bar for $C-E, 20 \mu \mathrm{m}$.

CCD camera (Panasonic WV-BD404, enhanced with a Hamamatsu DVS-3000) at rates dependent on the medium used to record them: every 1-4 sec if recorded onto a time-lapse video cassette recorder (Panasonic AG-6730) or every 15-180 sec if recorded directly onto a Macintosh computer via a frame grabber (LG3; Scion, Frederick, MD), using image analysis software (National Institutes of Health Image v 1.55, Wayne Rasband). Image contrast and enhancement were performed with image software. $\chi^{2}$ statistics were performed to assess growth cone behavior after encounters with individual tectal cells.

Expression of ephrin-A2 and ephrin-A5. Mouse ephrin-A2 was cloned, using PCR primers as described (Gao et al., 1996). Human ephrin-A5 was isolated by using a murine ephrin-A2 cDNA probe that was generously provided by D. Cerretti (Kozlosky et al., 1997). The ligands were expressed with a retroviral vector $\mathrm{pLIG}^{*}$, which contains a $\beta$-galactosidase gene fused to an aminoglycoside phosphotransferase for G418 selection (Lillian, 1996), as reported previously (Gao et al., 1996). 
Then the expression constructs were screened for ephrin-A2 or -A5 expression, using the extracellular domain of the Eph receptor EphA5 fused to the alkaline phosphatase (EphA5-AP; Flanagan and Leder, 1990; Gao et al., 1996). Briefly, cultures were incubated for $2 \mathrm{hr}$ in medium containing EphA5-AP at $20^{\circ} \mathrm{C}$ and rinsed with HBSS containing $0.5 \mathrm{mg} / \mathrm{ml} \mathrm{BSA}$ and $20 \mathrm{~mm}$ HEPES, pH 7.0. Cells were fixed for $30 \mathrm{sec}$ in a solution containing $60 \%$ acetone, $3 \%$ formaldehyde, and $20 \mathrm{~mm}$ HEPES, $\mathrm{pH}$ 7.5. Dishes were washed several times $(150 \mathrm{~mm} \mathrm{NaCl}$ and 20 mM HEPES, $\mathrm{pH} \mathrm{7.5),} \mathrm{incubated} \mathrm{at} 65^{\circ} \mathrm{C}$ for $15 \mathrm{~min}$, and washed again before color development $[0.17 \mathrm{mg} / \mathrm{ml}$ 5-bromo-3-indoyl-phosphate (BCIP), $0.33 \mathrm{mg} / \mathrm{ml}$ nitroblue tetrazolium, and $10 \mathrm{~mm}$ L-homoarginine]. The expression was confirmed further by Northern blot analysis (data not shown). Cell lines expressing high levels of EphA5-AP were used.

Immunohistochemistry. To distinguish between neuronal and nonneuronal cell types in the dissociated SC cultures, we applied a number of antibodies. Fragment $\mathrm{C}$ of tetanus toxin (Calbiochem, La Jolla, CA) and monoclonal antibody 18.2.12.6 (described in Kenimer et al., 1983) were generously provided by W. Habig, Food and Drug Administration (Washington, DC). Monoclonal antibodies developed by V. Lemmon (3A7 to vimentin-associated antigens and 8D9 to avian Ng-CAM; Lemmon and McLoon, 1986) and by F. Rathjen and S. Chang (12-I-4E-311 to avian Ng-CAM; Chang et al., 1990) were obtained as generous gifts Monoclonal antibodies developed by M. Yamamoto [RC2, to rodent radial glia (Misson et al., 1988, 1991; Takahashi et al., 1990)], by J. Wood [RT97, to polyphosphorylated neurofilaments (Wood and Anderson, 1981; Anderton et al., 1982)] and by Alvarez-Buylla [40EC, to radial glia (Alvarez-Buylla et al., 1987, 1988; Alvarez-Buylla and Nottebohm, 1988)] were obtained from the Developmental Studies Hybridoma Bank maintained by the Department of Pharmacology and Molecular Sciences, Johns Hopkins University School of Medicine (Baltimore, MD) and the Department of Biological Sciences, University of Iowa (Iowa City, IA) under contract N01-HD-2-3144 from the National Institute of Child Health and Human Development. GFAP was obtained from Boehringer Mannheim (Indianapolis, IN). Blocking sera and fluorescent secondary antibodies were obtained from Jackson ImmunoResearch (West Grove, PA).

With the exception of tetanus toxin fragment $\mathrm{C}$, which was applied to living cultures, all cultures were fixed at room temperature with freshly prepared $4 \%$ paraformaldehyde (Mallinkrodt, Paris, KY) for $\geq 2 \mathrm{hr}$ and washed several times with PBS (Life Technologies). Membranes were permeabilized with ice-cold methanol $\left(10\right.$ min at $\left.4^{\circ} \mathrm{C}\right)$ when RT-97, $40 \mathrm{EC}$, or GFAP was used. To block nonspecific antibody binding, we incubated cultures for $10 \mathrm{~min}$ with $10 \%$ normal goat serum. Primary antibodies were added at their appropriate dilution in blocking solution for $\geq 1 \mathrm{hr}$ at room temperature. Cultures were washed subsequently three times with PBS and a blocking solution to match the secondary antibody, either $10 \%$ normal goat or $10 \%$ normal donkey serum, for $\geq 30 \mathrm{~min}$ before the addition of appropriate fluorescent secondary antibodies. The following dilutions proved to be suitable for the identification of cells types: 8D9, 1:250; RT-97, supernatant full strength; 40EC, 1:2-1:20; RC2, 1:2; and GFAP, 1:4

To stain with fragment $\mathrm{C}$, we washed cultures in a minimal salt solution [containing (in mM) $145 \mathrm{NaCl}, 4.5 \mathrm{KCl}, 1.8 \mathrm{CaCl}_{2}, 0.8 \mathrm{MgCl}_{2}, 10$ glucose, and 10 HEPES] containing $2 \%$ BSA (RM/BSA) and incubated them on a rocker platform in a mixture of fragment $\mathrm{C}$ (final concentration, $1.3 \mu \mathrm{g} / \mathrm{ml})$ and 18.2.12.6 (1:2000; $4 \mu \mathrm{g} / \mathrm{ml})$ in RM/BSA for $30 \mathrm{~min}$ at room temperature.

CY3-labeled goat anti-mouse IgG (Jackson ImmunoResearch) was added to the cultures for $30 \mathrm{~min}$, washed, and fixed. Cultures were rinsed and stored in glycerol containing $20 \%$ of a saturated $N$-propyl gallate solution to prevent fluorescence photobleaching (Giloh and Sedat, 1982). Stained cells were viewed and photographed with a Zeiss Photomicroscope II (Oberkochen, Germany) and TMAX (3200 ASA) film.

To stain for ephrin-A2, we treated multiple SC cultures from each section in parallel with an antibody (1:200) from Santa Cruz Biotechnology (Santa Cruz, CA). After 5 d in culture, dishes were fixed and rinsed; primary antibody was added as described above. Then cultures were rinsed and stained with horseradish peroxidase (goat anti-rabbit $\operatorname{IgG}$ ) according to instructions (ABC kit, Vector Laboratories, Burlingame, CA) and processed with DAB for periods from $30 \mathrm{sec}$ to $5 \mathrm{~min}$. Stained cells were imaged under bright-field optics ( $40 \times$ objective) onto a Macintosh computer, as described above and reported as mean \pm SEM.

$R N A$ preparation and Northern blot analysis. Total RNA was extracted from tissue and cultured cells, using TRIzol (Life Technologies). Briefly, cultures were prepared in parallel from SC sections and allowed to grow for $5 \mathrm{~d}$. Then cultures were rinsed gently with PBS to remove media and serum components. Pools enriched for neuronal and non-neuronal cell types were collected by taking advantage of their different adhesive properties. Neuronal pools were collected by vigorously rinsing the dish with $1 \mathrm{ml}$ PBS, were spun for $10 \mathrm{sec}$ at 10,000 rpm, and immediately were resuspended into $1 \mathrm{ml}$ of TRIzol. After the dish was washed with copious amounts of PBS, a separate $1 \mathrm{ml}$ of TRIzol was washed across the remaining non-neuronal cells. Visual confirmation of cell type separation was made repeatedly and never failed to show a near-complete separation. RNA was separated on a $1.5 \%$ agarose gel with either 0.7 or $2.2 \mathrm{M}$ formaldehyde for $6-12 \mathrm{hr}$ at $40 \mathrm{~V} / \mathrm{cm}$. Electrophoresed RNA was transferred to a charged nylon membrane by passive capillary transfer and cross-linked to the membrane via UV. Blots were stained with $0.4 \%$ methylene blue (Sambrook et al., 1989) to ensure similar RNA loading and to stain RNA markers (0.24-9.5 kbp RNA ladder; Life Technologies) to obtain transcript sizes. Hybridization probes for ephrin-A2 and -A5 were obtained from cDNA inserts in pBluescript II KS phagemid obtained as a generous gift from Drescher, Bonhoeffer, and colleagues (Drescher et al., 1995; Monschau et al., 1997). Competent cells, HB101 (Life Technologies), were transfected and grown in $50 \mathrm{ml}$ of LB broth plus ampicillin $(100 \mu \mathrm{g} / \mathrm{ml})$. Using restriction enzymes KpnI and SacI, we obtained fragments of 950 and $700 \mathrm{bp}$ for ephrin-A2 probes for chick and mouse, respectively. Fragments of 310 and $500 \mathrm{bp}$ were obtained for ephrin-A5 probes for chick (HindIII and $X b a \mathrm{I}$ ), and a fragment of $900 \mathrm{bp}$ was obtained for mouse (EcoRI). Blots also were probed for G3PDH (Clontech, Palo Alto, CA) to normalize data for variations in RNA loading. Probes were random prime-labeled with ${ }^{32} \mathrm{P}-\mathrm{dCTP}$, using Rediprime reagents (Amersham), and were purified over a G50 Sephadex spin column (5 Prime-3 Prime, Boulder, CO). Equal counts were hybridized with blots in $0.1 \mathrm{mg} / \mathrm{ml}$ sheared DNA (Research Genetics, Huntsville, AL) at $68^{\circ} \mathrm{C}$ for $1.5 \mathrm{hr}$ in QuickHyb buffer (Stratagene, La Jolla, CA). The final wash was in $0.1 \times \operatorname{SSC}(1 \times=150 \mathrm{~mm} \mathrm{NaCl}$ and 15 $\mathrm{mm} \mathrm{NaCitrate)} / 0.1 \%$ sodium dodecyl sulfate at $60^{\circ} \mathrm{C}$ for $20 \mathrm{~min}$. Blots were quantified on a PhosphorImager (STORM 860, Molecular Dynamics, Sunnyvale, CA); the abundance of mRNA in all bands has been summed and normalized to G3PDH mRNA expression. All values for mRNA levels are given as an average \pm SD of at least three samples; statistical significance was determined and comparable, using the Student's $t$ test and the Mann-Whitney $U$ test.

Terminology. To ease discussion of comparisons between the rodent retinocollicular and avian retinotectal systems, we will use a single set of terminology to describe the different topographic axes: for the retinae, we will use temporal (posterior) and nasal (anterior); for the SC and optic tecta, we will use rostral (anterior) and caudal (posterior).

\section{RESULTS}

The present investigation combines a coculture assay with two model systems (the avian retinotectal system and the rodent retinocollicular system) commonly used to investigate mechanisms responsible for the precision of neuronal circuit formation. Three fundamental findings are presented in this manuscript concerning the cellular and molecular localization of guidance components that direct retinotopic map formation. First, we examined the response of RGC growth cones after contacting SC cells. This analysis revealed that living caudal SC cells from rodents indeed repel growth cones from temporal retinae and that there are both consistencies and notable inconsistencies when comparing these behaviors with those in the chick retinotectal system. Additionally, nonrepellent factors were identified in mouse and found to differ with those in the chick. Second, we demonstrated that fibroblast cells transfected with ephrin-A2 and -A5 can repel RGC growth cones both in a chamber assay and at the single-cell level. Both levels of examination demonstrated differences between the ability of each molecule to affect neuronal outgrowth. Third, we examined the expression pattern of ephrin-A2 and -A5 in the retinocollicular cocultures and noted a strong correlation between the repellent function of cells and their corresponding molecular expression pattern. Interestingly, these two molecules exhibit a strikingly different RNA expression pattern across neuronal and non-neuronal cell populations and 
across species. Together, these results establish critical factors that underlie and distinguish the development of retinotarget map formation across species.

\section{Living SC cells display repulsive characteristics}

To determine whether living dissociated cultures from caudal regions of rodent SC can prevent outgrowth selectively from chick and rodent temporal RGC axons, we used a three-compartment chamber (Fig. 1A). A representative example of the resultant outgrowth pattern from chick retinae is seen in Figure $1, B$ and $B^{\prime}$. Axons extended across rostral cells regardless of whether the retinal explant was obtained from nasal or temporal regions of the retinae (Fig. $1 B^{\prime}$ ). Axons extending toward dissociated caudal cells displayed a much different response: only nasal explants extended axons across caudal SC cells, whereas axons from temporal explants stopped at the border and appeared highly fasciculated (Fig. $1 B$ ). Both rat and mouse SC cells $(n=7$ rat; $n=19$ mouse) evoked this same pattern of axonal extension.

\section{Cellular recognition}

Using a number of antibodies, one readily can distinguish two cell types within young cultures (2-5 d in culture) of dissociated rodent SC (Fig. $1 C-E$ ). Neuronal markers, such as tetanus toxin/ fragment C (Fig. 1D), and antibodies to polyphosphorylated neurofilaments and to L1 selectively stain cells with round cell bodies, $\approx 10 \mu \mathrm{m}$ in diameter, and one to three long processes, usually $>200 \mu \mathrm{m}$. These cells were already immunopositive for neuronal markers and immunonegative for glial markers (e.g., GFAP; see below) by $2 \mathrm{~d}$ in culture and remained so for $>14 \mathrm{~d}$; they will be referred to as neurons. Cells immunonegative for neuronal markers generally were broad, flattened cells with epithelial-like morphologies. Non-neuronal cells in rodent SC cultures became GFAP-positive after $\sim 6 \mathrm{~d}$ in culture but were generally GFAP-negative before that. Essentially all nonneuronal cells were GFAP-positive after $12 \mathrm{~d}$ in culture. Consistent with previous observations (Dahl, 1981; Dahl et al., 1981; Lemmon and Rieser, 1983; Bignami and Dahl, 1989), these flat cells stained for vimentin (Dahl, 1981; Dahl et al., 1981; Bignami and Dahl, 1989). These non-neuronal cells likely represent the radial glial cells present in vivo, because they stain positive with the radial glial markers RC2 (Fig. 1E) and 40EC (Alvarez-Buylla et al., 1987, 1988; Alvarez-Buylla and Nottebohm, 1988; Misson et al., 1988, 1991; Takahashi et al., 1990; Marcus and Mason, 1995). As with radial glia from the optic chiasm of the mouse (Marcus and Mason, 1995; Marcus et al., 1995), staining of the flat cells with RC2 diminished during the first week in culture and was nearly absent by $14 \mathrm{~d}$ in culture. These cells will be referred to as glia or radial glia. Together, the neuronal and glial cells represented $>95 \%$ of the rodent SC cells in culture and were distinguished readily by consistent immunohistochemical and morphological criteria.

\section{Localization of repellent cues}

Time-lapse recordings were made 1-3 d after cultures were prepared as RGC growth cones encountered individual mouse SC neurons or glia. We used retinal explants from both chick and mouse to determine whether the RGC axon behavior on encountering living SC cells was different for the two species. To best characterize and to enable comparison with previous work, we grouped the behavior of growth cones into three distinct categories: an aversive response (collapse and retract), a permissive response (traverse), and a cessation or dramatic slowing of axonal extension with continued growth cone motility (attenuate). Inter- estingly, after contact with SC cells, growth cones displayed only aversive or permissive behaviors; the attenuation observed after contact with chick tectal cells did not occur. The distribution of repellent and permissive cues among SC cells is described below.

\section{Caudal neurons are generally repellent to temporal axons}

When temporal axons from either chick or mouse encountered individual neurons from caudal SC, they collapsed and retracted (Fig. 2A,C). The percentage of retracting mouse RGC growth cones $(77 \%, n=43)$ was similar to that of chick RGC growth cones $(74 \%, n=19 ; p>0.8)$. This growth cone behavior was a dramatic change that was scored easily (Fig. 4A,B). Retraction occurred at a rate of $50-100 \mu \mathrm{m} / \mathrm{hr}$, similar to that of forward advance. The collapse of growth cones was rapid and complete, with loss of both filopodia and lamellipodia. Entire RGC growth cones collapsed after as few as two filopodia contacted a caudal neuron. This aversive response was highly specific for temporal RGC growth cones contacting caudal neurons ( $p<0.0001)$.

For the most part, all other encounters between RGC growth cones and mouse SC neurons resulted in no discernible changes in growth cone behavior $(93 \%, n=43$ for chick RGC; $81 \%, n=$ 62 for mouse RGC; Figs. $2 B, D, 4 A, B)$. Neurons from rostral SC were traversed readily by both chick RGC growth cones (temporal $75 \%, n=16$; nasal $100 \%, n=14$ ) and mouse RGC growth cones (temporal $81 \%, n=37$; nasal $75 \%, n=12$ ). Nasal growth cones from both chick and mouse traversed caudal SC neurons $(100 \%, n=13 ; 85 \%, n=13$, respectively). The lack of retraction after such contact clearly was not dependent on the species of $\operatorname{RGC}(p>0.1)$.

\section{Aversive glia from mouse SC}

On encounter with caudal SC glia, approximately one-half of the temporal growth cones collapsed and retracted $(43 \%, n=99$ chick RGC; 58\%, $n=96$ mouse RGC; Figs. 3, 4C,D). Such frequent repulsion occurred significantly more often than after contact with glia from rostral SC or when nasal growth cones encountered caudal SC glia $(p<0.0001)$. Contact with caudal glia, however, resulted in a significantly lower frequency of aversive response than contact with caudal neurons $(p<0.0005)$. Additionally, in contrast to the response to caudal neurons, temporal growth cones did not retract from caudal glia after very limited filopodial contact (e.g., see Fig. $3 A$ ). Instead, the full lamellipodial expanse of the growth cone contacted caudal glia before revealing morphological changes associated with growth cone collapse. Moreover, not all growth cones necessarily would retract after contacting an individual glial cell. It is not clear whether differences in the response after contact with caudal SC neurons and glia reflect differences in molecular identity, concentration, or distribution of repellent cues. Contact with either caudal cell population could result in complete collapse and retraction of temporal growth cones, with loss of the entire lamellipodial and filopodial protrusions and retraction of the axonal process. A summary of the behavior of RGC growth cones after contact with SC glia is shown in Figure 4C,D.

After encounters with mouse SC glia, mouse RGC growth cones exhibited a higher tendency than chick RGC growth cones to collapse and retract (58 vs $43 \%$ for mouse and chick, respectively; $p<0.05)$. The difference between the frequency of collapse of mouse and chick RGC growth cones was more marked after other encounters of SC glia, i.e., temporal to rostral and nasal to rostral and to caudal glia (25 vs $8 \%$ for mouse mouse and chick, respectively; $p<0.002$ ). Accordingly, mouse SC glia 

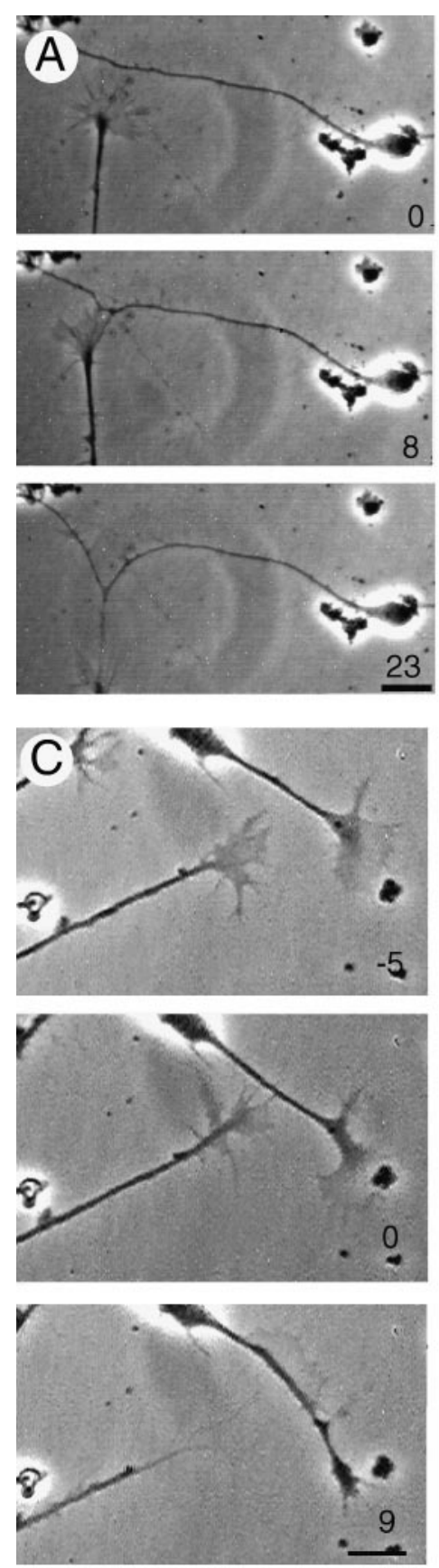
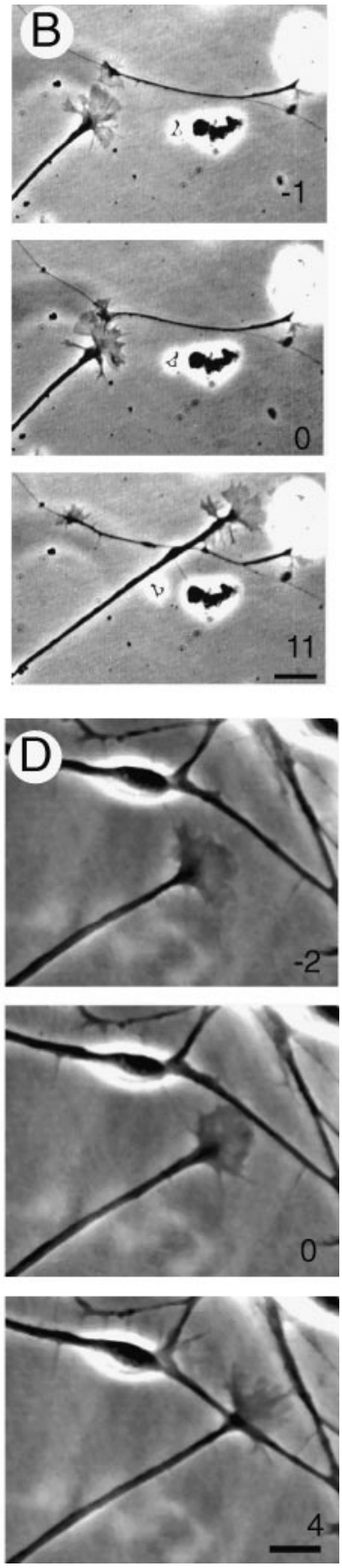

Figure 2. Time-lapse images of RGC growth cones encountering mouse SC neurons demonstrate selective repulsive behavior. $A$, Growth cones from temporal regions of chick retinae contacting neurons from caudal mouse SC collapse and retract. Temporal growth cones contacting rostral SC neurons are not repelled; similarly, nasal growth cones contacting either rostral or caudal SC neurons are not repelled. The images in $B$ show a representative example of a nasal growth cone contacting a rostral SC neuron. $C, D$, Time-lapse images of mouse RGC growth cones encountering $\mathrm{SC}$ neurons also demonstrate selective repulsion. $C$, Mouse temporal growth cones contacting caudal mouse SC neurons collapse and retract. Temporal growth cones contacting rostral SC neurons are not repelled, nor are nasal RGC growth cones contacting either rostral or caudal SC neurons. $D$, A representative example of a temporal growth cone contacting a rostral SC neuron. Times for the recorded images relative to contact are indicated in the bottom right of each panel. Scale bars for all images, $20 \mu \mathrm{m}$.
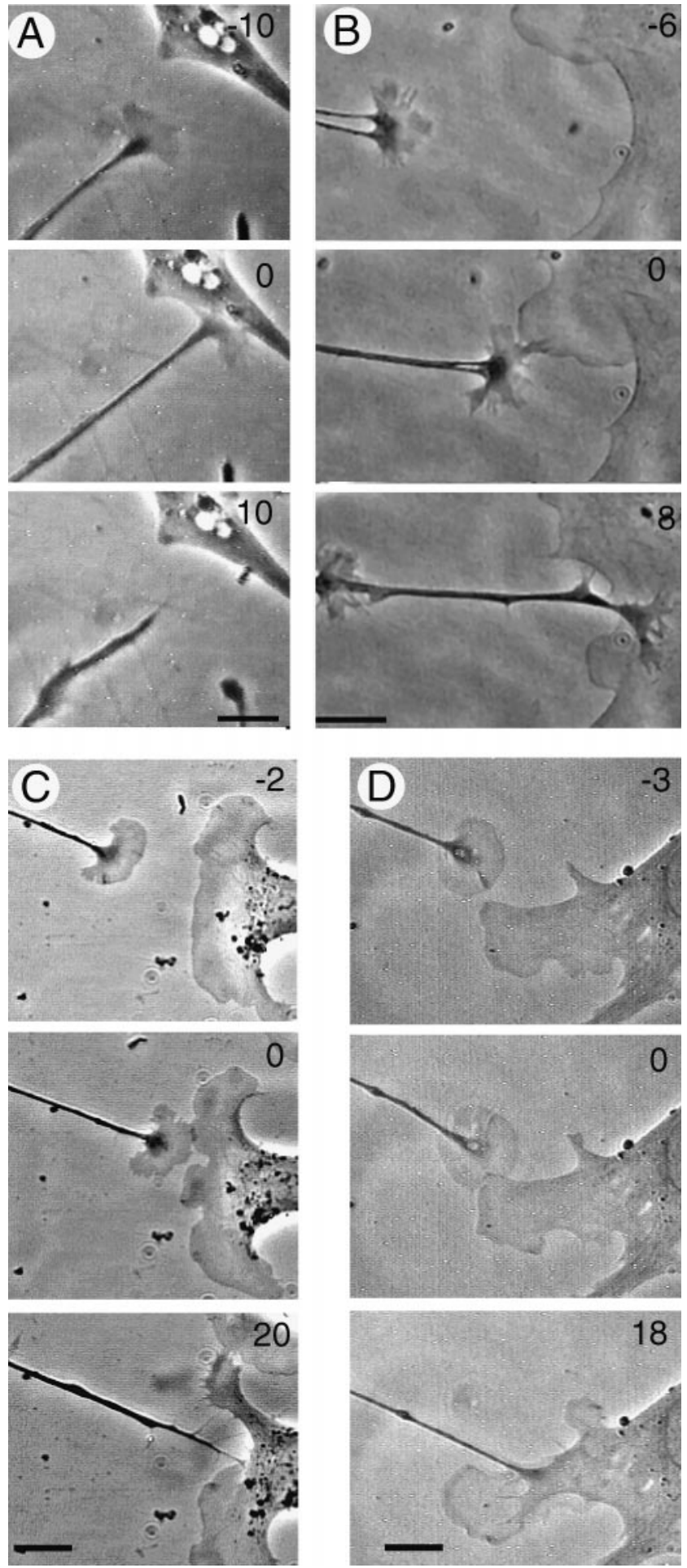

Figure 3. Time-lapse images of RGC growth cones encountering mouse SC glia revealed selective aversion of temporal growth cones away from caudal $\mathrm{SC}$ cells. The sequence in $A$ shows a temporal growth cone from chick retinae retracting from a caudal SC glia. Encounters between temporal RGC growth cones and rostral cells and between nasal RGC growth cones and either rostral or caudal SC cells usually resulted in unabated traversal of the glia. $B$, A nasal growth cone from chick retinae does not hesitate when encountering glia from rostral SC. Mouse temporal growth cones often collapse and retract from mouse caudal SC glia $(C)$; however, many continue to elongate $(D)$. Times for the recorded images relative to contact are indicated in the top right of each panel. Scale bars for all images, $20 \mu \mathrm{m}$. 
A

Chick RGC Encounters with mouse SC Neurons

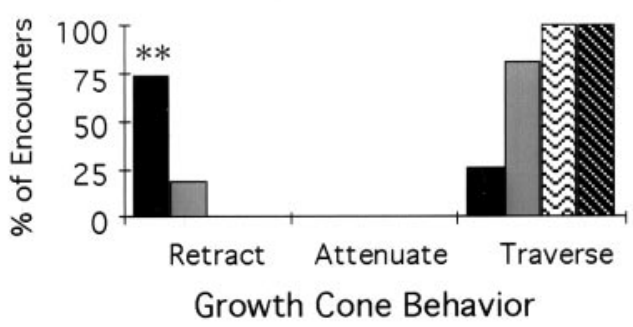

B Mouse RGC Encounters with mouse SC Neurons

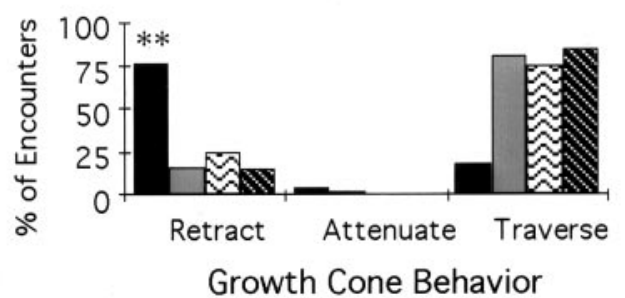

C Chick RGC Encounters with mouse SC glia

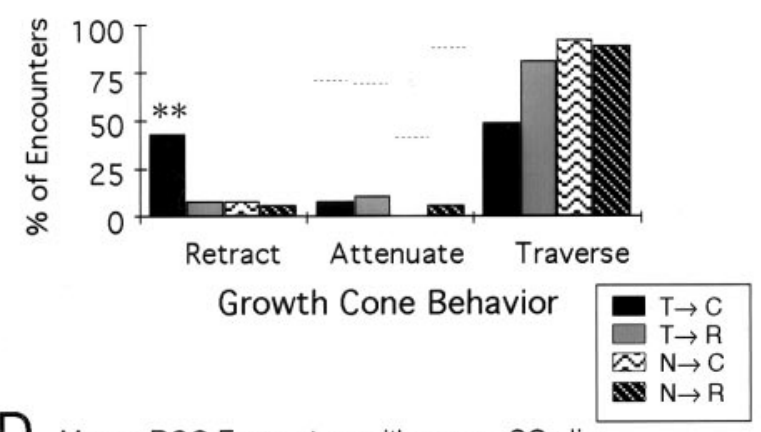

D Mouse RGC Encounters with mouse SC glia

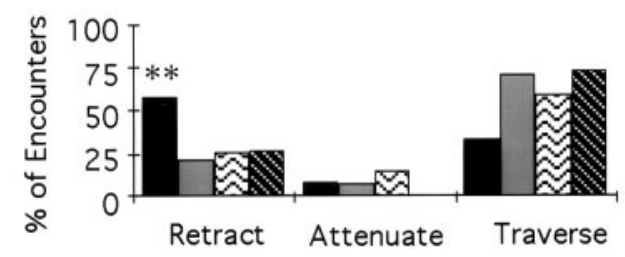

Growth Cone Behavior

Figure 4. The behavior displayed by RGC growth cones after encountering SC cells was scored into three categories. The histogram summarizes these data and reveals the dependence of the growth cone behavior on the origins of the respective SC neurons. Contact between temporal growth cones and caudal SC neurons evokes a consistent collapse and retraction, whether the RGC originated from chick $(A)$ or mouse $(B)$. Temporal growth cones readily traversed rostral neurons, as did nasal growth cones contacting either rostral or caudal neurons. $C$, Both nasal and temporal chick RGC growth cones primarily traversed glia from all regions of the SC they encountered. Approximately one-half of the temporal growth cones collapsed and retracted from caudal glia. Dashed lines indicate the percentage of chick RGC fibers that attenuated outgrowth after contacting chick tectal neuroepithelial cells in a previous study (Davenport et al., 1996). D, Contact between mouse temporal growth cones and caudal SC glia also resulted in collapse and retraction. Mouse temporal growth cones retracted from some rostral SC glia, although most traversed the glia similar to the traversal by nasal RGC growth cones of SC glia. Mouse RGC were more apt to collapse and retract from SC glia than chick RGC, regardless from which region of the retinae or SC the cells originated (compare $C, D) . T \rightarrow C, T \rightarrow R$, Temporal growth cones encounter caudal (black bars) or rostral ( gray bars) SC cells, respectively; $N \rightarrow C$, $N \rightarrow R$, nasal growth cones encounter caudal (zigzag bars) or rostral (striped bars) SC cells, respectively. ** $p<0.0001$ relative to the same response from other regions of retinae and $\mathrm{SC}$.

appear generally more aversive to RGC growth cones from mouse than from chick (Fig. 4C,D). Contact with mouse SC neurons, on the other hand, resulted in similar behavior from chick and mouse RGC growth cones: temporal growth cones collapsed and retracted from caudal SC neurons with similar frequency (74 and 77\%, respectively; $p>0.8$ ) and traversed rostral SC neurons with similar frequency (75 and $81 \%$, respectively; $p>0.6)$.

\section{Uninterrupted outgrowth across SC glia}

If $\mathrm{RGC}$ growth cones were not repelled by their initial contact with SC glia, then the growth cones seemed to continue unimpeded extension, even after complete contact with SC glia (Fig. $3 B, D)$. If one considers growth cone-glial encounters other than temporal RGC to caudal SC glia (i.e., both temporal and nasal growth cone to rostral SC and nasal growth cone to caudal SC), a majority resulted in growth cones extending onto the glia (79\%, $n=105$ for chick RGC; $52 \%, n=63$ for mouse RGC). Among these encounters no significant differences were detected between regions of the retinae or SC $(p>0.1$; Fig. $4 C, D)$. Very few RGC axons behaved in any way other than retraction or unhindered outgrowth. We paid particular attention to a growth cone behavior that we previously termed attenuation, in which axons cease to elongate and appear to adhere to the edge of non-neuronal cells (Davenport et al., 1996). (The frequent attenuation of chick RGC growth cones after contact with chick tectal neuroepithelial cells is indicated by dashed lines in Fig. 4C.) After temporal growth cone encounter of caudal SC glia, only $8 \%$ of both chick and mouse RGC outgrowth was attenuated $(p>0.9)$. Similarly, after other growth cone encounters with SC glia, i.e., temporal growth cone to rostral SC and nasal growth cone to rostral and to caudal SC glia, only $8 \%$ of both chick and mouse RGC outgrowth was attenuated $(p>0.9)$. In general, if SC glia did not produce retraction, they were quite supportive of continued ganglion cell outgrowth.

\section{Cellular expression of ephrin-A2 and ephrin-A5: transfected fibroblasts repel retinal outgrowth}

To determine how well the individual molecules ephrin-A2 and -A5 could mimic the pattern of RGC outgrowth, we transfected National Institutes of Health-3T3 (NIH-3T3) cells with each molecule and assessed them for their effect on neuronal outgrowth in the same coculture assay (Fig. 5). Both molecules could strongly diminish the extension of axons as they encountered regions of the dish occupied by transfected cells (Fig. 5, middle column). Ephrin-A2 limited the extension of RGC fibers from temporal retinae $(79 \pm 20 \mu \mathrm{m}, n=26$ lanes in four dishes; $p<$ 0.05 when compared with control NIH-3T3 cells). Ephrin-A5 limited the extension of both temporal and nasal outgrowth (105 $\pm 17 \mu \mathrm{m}, n=73$ lanes in 11 dishes; $121 \pm 26 \mu \mathrm{m}, n=63$ lanes in 11 dishes; $p<0.005)$. Outgrowth was limited similarly in each case, i.e., temporal axons across ephrin-A2 cells, temporal axons across ephrin-A5 cells, and nasal axons across ephrin-A5 cells $(p>0.3)$. Axons from both nasal and temporal retinal explants extended well across control NIH-3T3 cells. There was similarly no difference in the extension across control cells (tem- 

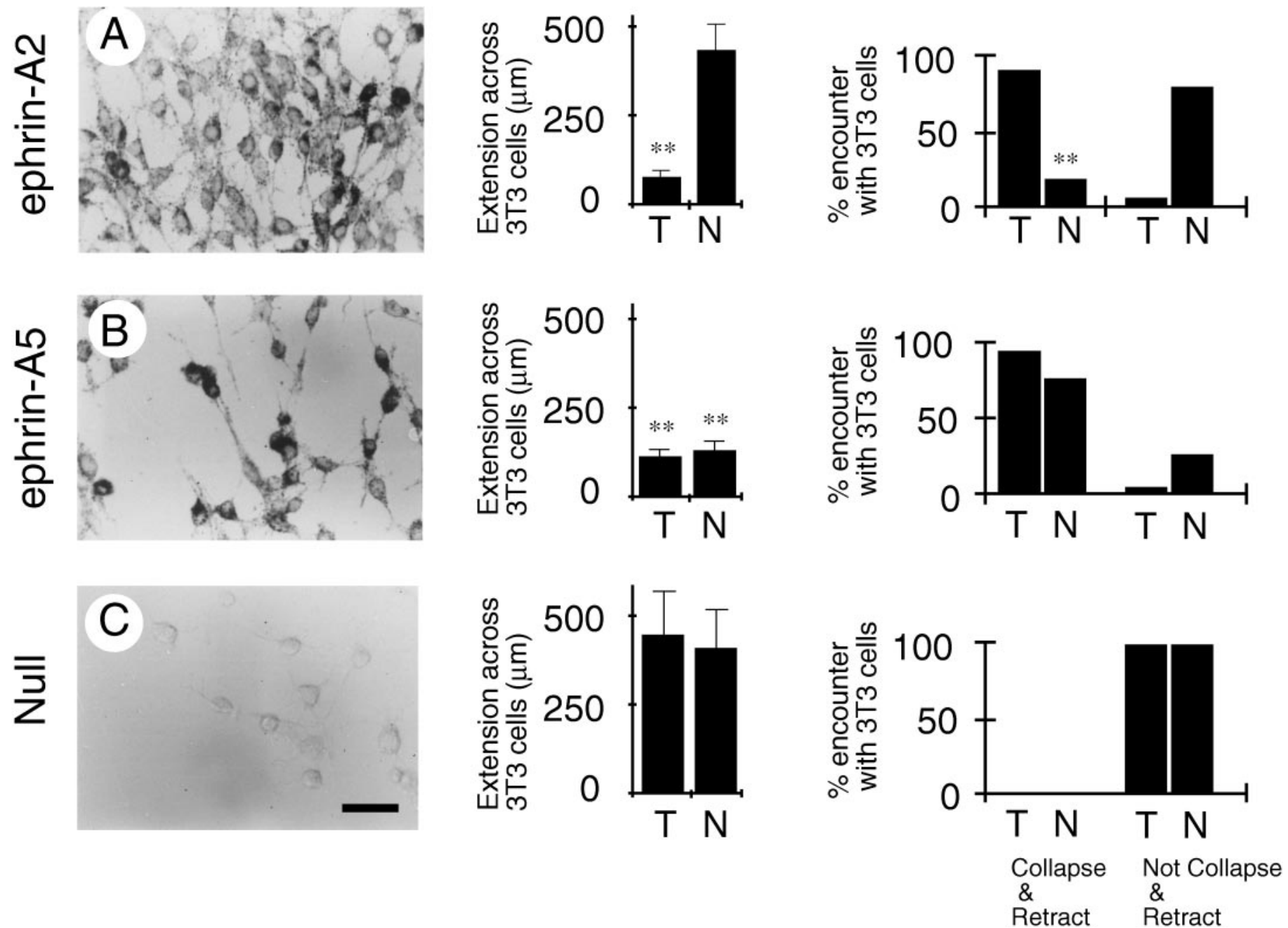

Figure 5. Fibroblast cells transfected with ephrin-A2 or ephrin-A5 are effective at averting axonal outgrowth and evoking growth cone collapse. NIH-3T3 cells were transfected with ephrin-A2 $(A)$, ephrin-A5 $(B)$, or neither $(C)$. The images shows staining of transfected NIH-3T3 cells with a ligand affinity probe, EphA5-AP, which consists of the extracellular domain of EphA5 tagged with alkaline phosphatase. When placed into the center compartment of a three-compartment chamber, transfected fibroblasts limited RGC fibers extension (middle column) and caused contacting RGC growth cones to collapse and retract (right column). A, Ephrin-A2 significantly limited outgrowth and evoked retraction of temporal, but not nasal, RGC axons. $B$, Ephrin-A5 repelled all RGC fibers and growth cones. $C$, Control cells that were not transfected did not perturb axon extension or growth cone behavior. Scale bar, $20 \mu \mathrm{m} .{ }^{* *} p<0.001$.

poral axons $413 \pm 114 \mu \mathrm{m}, n=18$ in four dishes; nasal axons $380 \pm 103 \mu \mathrm{m}, n=28$ lanes in four dishes; $p>0.8)$ and in the extension of nasal axons across ephrin-A2 cells $(437 \pm 70 \mu \mathrm{m}$, $n=46$ lanes in five dishes; $p>0.6$ ). Axons either extended across the NIH-3T3 cells fully or were repelled similarly: ephrin-A2 repelled temporal axons, whereas ephrin-A5 repelled both nasal and temporal axons.

Time-lapse recordings were made to determine whether the repulsion observed in the present chamber assay also could be observed when individual RGC growth cones contacted individual cells expressing ephrin-A2 or -A5 (Fig. 5, right column). The results from these recordings are consistent with the overall effect of the cells on outgrowth: ephrin-A2 cells selectively repelled temporal growth cones $(93 \%, n=28, p<0.0001$ when compared with control cells), whereas ephrin-A5 cells repelled both temporal and nasal growth cones $(95 \%, n=20, p<0.0001$; and $75 \%$, $n=12, p<0.001$, respectively). None of the RGC growth cones retracted from the control NIH-3T3 cells. The collapse and retraction of growth cones after contact with the transfected
NIH-3T3 cells could not be distinguished from the response to the caudal SC neurons. Contact from a limited number of filopodia (from one to three) was sufficient to induce the entire RGC growth cone to collapse. Growth cones that did not collapse displayed a variety of behaviors but did not exhibit repulsive behavior. Together, the data strongly support the notion that ephrin-A2 and -A5 both can repel axonal extension even when expressed at the single-cell level. At the level of resolution of the behavior of a single growth cone, ephrin-A5 repels both nasal and temporal growth cones, whereas ephrin-A2 repels only temporal growth cones.

\section{Cellular expression of ephrin-A2 and ephrin-A5: resolution across target cells}

The characteristic growth cone behavior observed after RGC growth cones contact either their target cells or cells expressing ephrin-A2 or -A5 enabled an attempt to correlate directly the function of these guidance cues with their cellular expression patterns. The expression of ephrin-A2 and -A5 was examined 


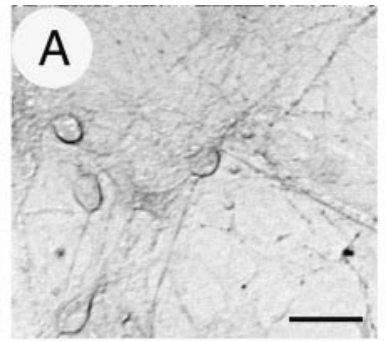

(B) Chick Optic Tecta

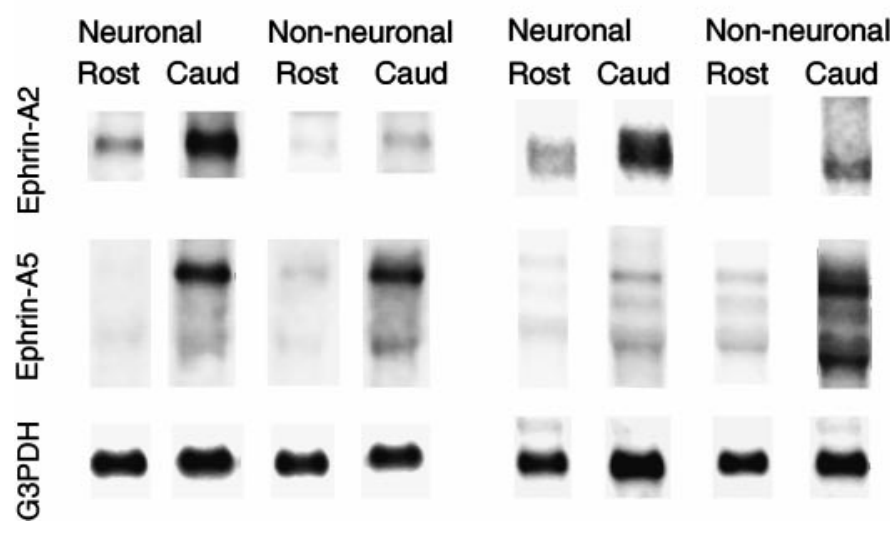

Figure 6. Ephrin-A2 and ephrin-A5 in primary cultures from chick optic tecta and mouse $\mathrm{SC}$ are shown with immunostaining (ephrin-A2 on mouse cultures; $\left.A, A^{\prime}\right)$ and with Northern blot analysis $(B, C)$. Staining of mouse SC cultures with an antibody to ephrin-A2 shows immunopositive staining for neurons from caudal SC $(A)$ when compared with rostral SC cultures $\left(A^{\prime}\right)$. Pools of RNA enriched for neuronal or non-neuronal cells were collected from multiple dissociated cultures ( $5 \mathrm{~d}$ in culture) of rostral and caudal regions of chick optic tecta $(B)$ and mouse SC $(C)$. Blots contained $15 \mu \mathrm{g}$ of total RNA and were hybridized and stripped sequentially with species-specific probes for ephrin-A2 and -A5, as well as G3PDH. Scale bar in $A, 20 \mu \mathrm{m}$.

across the neuronal and non-neuronal cell populations of both chick tecta and mouse SC to determine whether and in which cell population of retinal targets the repellent molecules are expressed. Dividing the SC into three sections (see Fig. $1 A$ ), we made dissociated cultures from each. An antibody to ephrin-A2 selectively stained neurons in dissociated cultures from caudal SC. Measuring the intensity of staining from 100 cells in each of three cultures revealed a statistically significant staining of caudal neurons when compared with non-neuronal cells from the same region $(p<0.0001)$. There was a robust increasing gradient of immunostaining as parallel cultures of mouse midbrain were made from rostral to caudal SC. Representative stainings are shown in Figure $6 A$ for separate sections. Caudal neurons were stained strongly when compared with rostral neurons $(49 \pm 1.2$ and $32 \pm 1.2$ arbitrary units, respectively, 300 cells from $n=3$ separate cultures; $p<0.0001)$. Staining of non-neuronal cells did not differ across these regions $(8.3 \pm 1.1$ and $6.9 \pm 1.3$ arbitrary units, respectively; $p>0.4$ ). This antibody did not stain chick cells.

To examine the mRNA levels for both molecules and in both systems, we collected neuronal and non-neuronal pools from both rostral and caudal regions and ran them in parallel lanes. Individual blots containing all four samples from one species were probed for ephrin-A2 and -A5, as well as for G3PDH. Expression
Table 1. RNA expression levels in retinotarget cell populations

\begin{tabular}{llll} 
& $\begin{array}{l}\text { Ratio of caudal } \\
\text { neurons vs } \\
\text { non-neuronal } \\
\text { cells }\end{array}$ & & Ratio of caudal vs rostral cells \\
\cline { 4 - 4 } & & Neuronal & Non-neuronal \\
\hline $\begin{array}{l}\text { Ephrin-A2 } \\
\text { Chick }\end{array}$ & $7.5 \pm 2.0(4)$ & $3.3 \pm 0.3(4)$ & n.e. \\
$\begin{array}{l}\text { Mouse } \\
\text { Ephrin-A5 }\end{array}$ & $4.8 \pm 0.6(4)$ & $1.8 \pm 0.3(4)^{*}$ & n.e. \\
Chick & $2.9 \pm 0.9(3)$ & $13.2 \pm 6.8(3)$ & $4.3 \pm 2.2(3)$ \\
Mouse & $0.2 \pm 0.1(3)^{*}$ & n.e. & $5.0 \pm 1.0(4)$
\end{tabular}

n.e., Neither cell population expressed $>20 \%$ of peak expression levels; mean \pm SE $(n) ;{ }^{*} p<0.05$ between chick and mouse.

levels of ephrin-A2 and -A5 were normalized to G3PDH, although none of the conclusions differed if normalization was not performed. A single band was identified for ephrin-A2, whereas multiple bands were detected for ephrin-A5. Expression of each molecule differed in several respects, depending on (1) the cell type in which it was expressed, (2) the distribution across rostral and caudal target regions, and (3) whether the target cells were derived from chick or from mouse. These points are discussed for each molecule below.

\section{Cellular expression of ephrin-A2}

Probes for ephrin-A2 consistently labeled a strong band in caudal neuronal pools from both chick and mouse (Fig. 6B,C). This band ran at $\sim 2.5 \mathrm{kbp}$ in blots from both chick $(2.7 \mathrm{kbp} \pm 0.2, n=4)$ and mouse $(2.2 \mathrm{kbp} \pm 0.2, n=4)$. In both chick and mouse the caudal neuronal pool showed a much stronger expression of the ephrin-A 2 band when compared with the caudal non-neuronal pool (five- and sevenfold, respectively; Table 1). Within the neuronal pools an increasing gradient of ephrin-A2 expression from rostral to caudal was significant in both chick $(3.3 \pm 0.3, n=4)$ and mouse $(1.8 \pm 0.3, n=4)$ but was larger in chick than in mouse $(p<0.03)$.

\section{Cellular expression of ephrin-A5}

Probes for ephrin-A5 consistently labeled multiple bands that most strongly appeared in the non-neuronal pools from caudal regions of chick and mouse (Fig. 6B,C). Interestingly, these bands also appeared in the caudal neuronal pool from chick, but much less so in mouse, neurons (see below). The most prominent bands were a triplet in mouse of $\sim 7.2,5.9$, and $4.2 \mathrm{kbp}$ and a doublet in chick of $\sim 6.4$ and $3.8 \mathrm{kbp}$. The doublet appeared similar to the upper and lower bands of the mouse and likely reflects the same bands as those reported by Drescher et al. (1995). In both chick and mouse a smaller band appeared in all blots of $\sim 1.7 \mathrm{kbp}$ (chick $1.7 \pm 0.1 \mathrm{kbp}, n=3$; mouse $1.8 \pm 0.2 \mathrm{kbp}, n=4$ ). Each of the ephrin-A5 bands consistently showed a similar distribution across rostrocaudal dimensions and neuronal/non-neuronal cell types.

Both chick and mouse similarly expressed much more ephrin-A5 mRNA in non-neuronal cells from caudal target areas than in rostral cells (four- and fivefold, respectively; $p>0.5$ ). In mouse ephrin-A5 expression was higher in glia than in neurons (Table 1). Ephrin-A5 was expressed at low levels in mouse caudal SC neurons, similar to that in rostral SC cells (the ratio was near unity: $1.4 \pm 0.8, n=3 ; p>0.4)$, whereas expression in caudal SC glia was eightfold higher. This contrasts sharply with the large ( $>13$-fold) caudal-to-rostral gradient within chick neurons. In chick, ephrin-A5 was expressed similarly in caudal neuronal and 


\begin{tabular}{lll}
\hline $\begin{array}{l}\text { Table 2. Common RGC growth cone behavior in response to contact } \\
\text { with target cells }\end{array}$ & $\begin{array}{l}\text { Rodent } \\
\text { retinocollicular }\end{array}$ \\
Retinae $\rightarrow$ Target cell & $\begin{array}{l}\text { retinotectal } \\
\text { Temporal } \rightarrow \text { Caudal }\end{array}$ & $\begin{array}{l}\text { Repulsive } \\
\text { Neuron }\end{array}$ \\
Non-neuronal & Repulsive & Attenuating \\
Temporal $\rightarrow$ Rostral & Pepulsive \\
Neuron & Permissive & $50 \%$ permissive \\
Non-neuronal & Attenuating & Permissive \\
Nasal $\rightarrow$ Caudal & & Permissive \\
Neuron & Permissive & \\
Non-neuronal & Attenuating/tracking & Permissive \\
Nasal $\rightarrow$ Rostral & & \\
Neuron & & Permissive \\
Non-neuronal & Permissive & Permissive \\
\hline
\end{tabular}

non-neuronal tectal cells in one blot and approximately threefold higher in neurons in two other blots (Table 1). Thus, a striking difference exists between the cellular distribution of ephrin-A5 expression in chick and mouse $(p<0.05)$.

In a previous report ephrin-A5 displayed a steeper immunohistochemical expression pattern than ephrin-A2 across the chick tecta (Monschau et al., 1997). In the present study the average ratio of RNA expression in caudal versus rostral cells often was greater for ephrin-A5 than for ephrin-A2 (Table 1). Considering each of the blots independently, the ratio of caudal versus rostral cell expression was greater for ephrin-A5 $(7.2 \pm 2.3, n=10)$ than for ephrin-A2 $(2.6 \pm 0.3, n=8 ; p<0.05)$. Thus, the cellular RNA expression patterns are consistent with overall tectal protein expression patterns.

The species differences in the cellular distribution of ephrin-A2 and -A5 can be summarized: (1) there is a larger rostrocaudal gradient per target nuclei for ephrin-A2 in chick neurons than in mouse neurons; (2) chick neurons express similar or higher levels of ephrin-A5 than chick glia, whereas mouse neurons express much less ephrin-A5 than mouse glia; (3) there is a very large rostrocaudal gradient for ephrin-A5 in the chick, whereas there is little expression of ephrin-A5 in mouse neurons and no significant rostrocaudal gradient for ephrin-A5 in these cells.

\section{DISCUSSION}

The establishment of topographic maps represents a complex and critical series of cellular and molecular interactions directed by highly dynamic growth cone behavior that, in turn, is regulated by interaction with target cells. The present investigation addresses retinotopic formation by contrasting these growth cone behaviors across regions of both retinae and their targets. Existence of discreet guidance components is inferred from the characteristic growth cone behavior after contact with individual target cells. The different guidance components fall into three distinct categories: repulsive, attenuating, and permissive (Table 2). Interestingly, the retinocollicular and retinotectal cocultures displayed overlapping, but different, categories of guidance components. Consistent with functional differences, expression levels of repellent molecules differ across cell types and across species. Put together, the multiple guidance signals may determine how de- velopment of retinotopic order proceeds in the two species and explain differences in the early stages of retinotectal and retinocollicular map formation.

\section{Localization of retinocollicular guidance components}

Although temporal axons in the rodent are repelled by caudal SC membrane fractions in vitro (Godement and Bonhoeffer, 1989; Simon and O'Leary, 1992), these same axons extend well across living caudal cells in vivo (Godement et al., 1984; Simon and O'Leary, 1992; Roskies and O'Leary, 1994). The retinocollicular cocultures allowed us to assess generally the ability of temporal axons to extend across living caudal SC cells. The selective lack of extension of temporal axons observed in the present assay is consistent with recent findings using chick tectal cells (Davenport et al., 1996) and is similar to previous results that used membrane fractions. Thus, it is likely that living caudal SC cells in vivo also express sufficient amounts of repellent cues and that previous experimental observations using membrane fractions did not result from simple artifact(s) caused by cell fractionation. The present results suggest instead that species-specific guidance components or distributions of guidance components may be critical to the early stages of chick retinotectal and rodent retinocollicular map formation. The coculture system provides evidence for both alternatives.

\section{Repellent cues}

Results from time-lapse video microscopy of mouse cocultures lie between previous results from Xenopus (Johnston and Gooday, 1991) and chick (Davenport et al., 1996) cocultures: like the chick, most caudal neurons repelled temporal growth cones, but additionally many of the caudal glia did as well. The aversive response evoked by caudal SC neurons demonstrates that neuronalmediated repulsion is conserved across avian and rodent systems. Given the more robust outgrowth of rodent RGC axons across the SC, we had expected to find fewer repellent cells in retinotarget cocultures from mouse than from chick; therefore, retraction from target glia was an unexpected observation and suggests that in similarly prepared cultures there may be more aversive caudal cells in mouse than chick. To account for differences in retinotopic development, we now must consider alternative explanations, such as distinct cellular distributions and different gradients of the candidate repulsive molecules.

\section{Permissive cues}

The uninterrupted outgrowth observed as mouse RGC growth cones continued from a laminin-coated substratum onto SC glia indicates that permissive guidance components, for which the support of outgrowth rivals that of laminin, are expressed on the surface of glia across the SC. The behavior of RGC growth cones after encounter with mouse SC glia was in striking contrast to the response of chick RGC growth cones encountering non-neuronal cells from the chick tecta (Davenport et al., 1996) (Table 2). In those chick-chick encounters, outgrow th was attenuated; that is, growth cones dithered at the edge of non-neuronal tectal cells, whereas elongation was reduced substantially (see http://mecko. nichd.nih.gov/LDN_Labs/NelsonLab/Davenport/Roger.html). The molecules responsible for the growth-supporting and attenuating behavior are not known; however, future investigations can elucidate whether the attenuation components are present but are overridden by the supportive components in mouse, or vice versa. We hypothesize that both may serve critical roles in the extent of optic fiber outgrowth in each 
species: the permissive and outgrowth-promoting cues on SC cells may be responsible for the rapid outgrowth of optic fibers across the SC in vivo (Lund and Bunt, 1976), whereas the adhesive cues in chick may help restrict optic fibers to the narrow stratum opticum in the uppermost layer of the optic tectum (Vanselow et al., 1989).

\section{Ephrin-A2 and ephrin-A5 repel RGC axons when expressed on living cells}

Transfected fibroblast cell lines expressing either ephrin-A2 or -A5 limited the extension of RGC axons. Ephrin-A2 repelled growth cones specifically from temporal RGC fibers, whereas ephrin-A5 repelled growth cones from both temporal and nasal RGC fibers, consistent with previous experiments using transfected cell membranes (Drescher et al., 1995; Nakamoto et al., 1996; Monschau et al., 1997) and infected tecta (Nakamoto et al., 1996). In the present experiments growth cones collapsed after only a small number of filopodia contacted either type of transfected cell in a manner similar to that observed after contact with primary cultured cells, suggesting that the receptive components necessary to transduce repellent guidance cues are constitutively expressed at high levels. Therefore, it seems unlikely that limited amounts of receptors or transduction components in RGC growth cones determine growth cone behavior during retinotopic map formation. Alternative mechanisms must reconcile the retraction of nasal growth cones from ephrin-A5 in culture despite its expression in caudal target areas, the natural target zone for nasal RGC axons. The most plausible explanations, that expression of ephrin-A5 is limited in amount and/or is restricted to particular cell populations, were examined in the present coculture paradigm.

\section{Cellular localization of repellent cues matches functional expression}

Examining the expression of ephrin-A2 and -A5 across cell populations in both tectal and SC cultures suggests that these molecules can account for repellent behavior in both the mouse and chick (see below). However, striking differences in RNA expression were noted between molecules, across cell types, and between species (Table 1). These are discussed briefly below; their potential implications are discussed in the next section.

Ephrin-A2 is highly expressed on caudal neurons in both chick and mouse cultures; therefore, its expression could mediate most of the observed repulsion. The slope of the rostrocaudal gradient per target nuclei was significantly more shallow for mouse SC neurons than for chick tectal neurons. Despite the lower slope across the $\mathrm{SC}$, mouse neurons did express a significant gradient of ephrin-A2 on their surface, as detected by both immunostaining and Northern analysis. Also, mouse neurons were able to repel temporal growth cones from both mouse and chick retinae. Together, the data suggest that the ephrin-A2 gradient is likely to be functionally relevant in both systems, but it may be more effective at limiting temporal RGC outgrowth in chick tecta than in mouse SC.

In mouse SC cultures ephrin-A5 is expressed predominantly on non-neuronal cells from caudal regions and therefore may account for the repulsion observed in response to this cell population. Several lines of evidence, however, suggest that the expression level of ephrin-A5 may be relatively low: (1) Growth cones from temporal but not nasal retinae retracted to the mouse SC glia; such specificity of ephrin-A5 for temporal RGC growth cone behavior has been observed only at low concentrations (Monschau et al., 1997). (2) Only one-half of the interactions between temporal growth cones and mouse caudal non-neuronal cells evoked collapse. (3) Individual non-neuronal cells caused only some of the contacting temporal growth cones to collapse; other later-arriving growth cones did not retract from the same cell. It therefore appears that ephrin-A5 is expressed on SC cells at a functional but minimal level. In addition to allowing extensive outgrowth across rodent SC, this would enable a more specific repulsion of temporal RGC axons.

Interestingly, the RNA expression pattern of ephrin-A5 in mouse SC cultures differed from that in chick tectal cultures in which it was expressed similarly on both neuronal and nonneuronal cells from caudal tecta. It is likely that the expression of ephrin-A5 in chick cultures also was relatively low, because neither temporal nor nasal growth cones retracted from the nonneuronal tectal cells (Davenport et al., 1996). It is possible that some repellent behavior was masked by the adhesive cues that are present specifically on non-neuronal cells from chick. It is unlikely, however, that ephrin-A5 underlies the adhesive interactions, as suggested by Nakamoto et al. (1996), because attenuated outgrowth was observed in chick with similar frequency after growth cone contact with either rostral or caudal tectal cells, yet the present results demonstrate ephrin-A5 expression only in the caudal tectal cells. Additional factors must be responsible for the adhesive components that were detected specifically in chick cocultures.

\section{Multiple retinocollicular and retinotectal guidance components result in strategic differences in development of retinotopic maps}

The coculture system that has been presented serves as a model for the elaborate growth cone navigation that occurs in vivo. In single retinotarget encounters in culture, individual cell-cell interactions were assessed with high resolution. Although it cannot be determined if all relevant molecules are expressed similarly after cells are cultured, several functional guidance components were compared after similar experiments were performed in chick and mouse, and the responses to both neurons and glia were recorded. Resulting differences between species and between cell types suggest basic mechanisms that may underlie retinotopic development in vivo.

Species differ in the extent to which individual RGC axons spread across their targets before their projections become retinotopic, as well as the laminae within which specific stages of axonal growth occur. In chicks, optic fibers grow across the surface of the tecta in the uppermost (stratum opticum; SO) layer, whereas in rodents RGC axons grow transiently across the entire rostrocaudal extent of the SC within both the superficial gray layer and the underlying SO; later, RGC axon trunks become restricted to the SO and arborize in their topographically appropriate target zone. The more permissive nature of most of the SC glia may partially underlie the profuse and rapid extension of rodent RGC axons initially through multiple medial layers of the SC (Lund and Bunt, 1976; Sachs and Schneider, 1984; Stein, 1984; Edwards et al., 1986a; Frost et al., 1986). The ability of non-neuronal cells in the chick tecta to attenuate RGC outgrowth may serve to restrict RGC axons to the most superficial layers of the tecta (Fig. 7). Extension along the SO in chick, therefore, likely would ensure RGC growth cone contact with glial endfeet, where ephrin-A5 appears to be localized (Monschau et al., 1997). In the mouse, extension across deeper laminae may result in RGC growth cones avoiding these repellent glial endfeet. Additionally, rodent fibers initially may encounter less repellent regions of target neurons, because distal portions of target neurons are more likely to evoke RGC growth 
chick

1

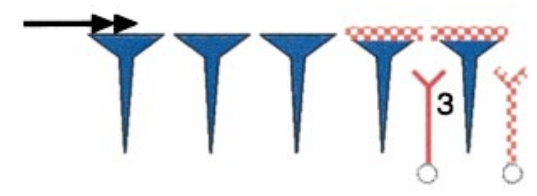

mouse

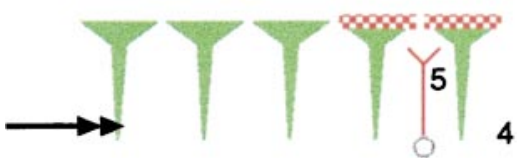

4

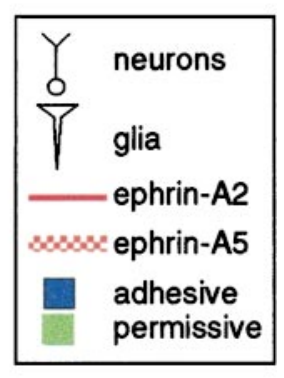

Figure 7. Schematic diagram contrasting the development of the retinotectal and retinocollicular systems in chick and mouse. Optic fibers (double-headed arrows) extend from rostral to caudal target regions at different depths. In chick, fibers may be restricted to the uppermost SO layer by the adhesive cues present on tectal glia (1) and thereby encounter ephrin-A5 (2), which is expressed on radial glial endfeet (Monschau et al., 1997). Ganglion cell growth cones may contact the extending processes of tectal neurons (3), which are more repellent than tectal cell bodies (Davenport et al., 1996). In mouse, optic fibers extend rapidly in less restricted laminae across the deeper superficial gray layer and SO, perhaps as a result of the permissive components expressed on their glia. Extension across these deeper layers may allow growth cones to avoid ephrin-A5 expressed on glial endfeet and the more repellent expression of neuronal processes. Optic fibers in the mouse do not encounter substantial amounts of ephrin-A5 on SC neurons (4), and they detect a more shallow gradient of ephrin-A2 across their targets (5). These points suggest causal mechanisms underlying key differences in both the laminae and extent of optic fiber outgrowth in chicks and rodents.

cone collapse than target cell bodies (Davenport et al., 1996). The same attenuation/adhesive cues additionally may slow chick RGC outgrowth, thereby enabling their prompt restriction by repulsive, caudal neurons. Thus, the greater (over-) extension of rodent RGC axons in vivo into caudal target areas may result in part from the more permissive components on glia.

Differences in the distribution of repellent components also may contribute to the transient overshoot of rodent axons. When compared with chick, mouse RGC may overshoot target zones in part because they encounter fewer restrictive cues: mouse SC neurons express little ephrin-A5 as compared with chick, and mouse SC neurons express a less steep slope of ephrin-A2 across their targets. In both systems repellent cues in caudal target regions eventually limit the extension of fibers from temporal retinae. In the mouse they also may account for the subsequent removal of optic fibers from the superficial gray layer as SC neurons begin to elaborate and arborize in this region (Lund and Bunt, 1976; Altman and Bayer, 1981; Edwards et al., 1986a,b). Consequently, the overshoot of RGC fibers is limited in the rostrocaudal dimension and restricted to a narrower lamina only after its initially robust extension.

Together, these guidance components appear to serve an essential role in directing RGC growth cones toward their target zones and also account for early differences in the projection of RGC axons across their targets. The demonstration that the underlying functional guidance components differ at the molecular level between species and cell types elucidates key guidance strategies used during retinotectal and retinocollicular development.

\section{REFERENCES}

Altman J, Bayer SA (1981) Time of origin of neurons of the rat superior colliculus in relation to other components of the visual and visuomotor pathways. Exp Brain Res 42:424-434.
Alvarez-Buylla A, Nottebohm F (1988) Migration of young neurons in adult avian brain. Nature 335:353-354.

Alvarez-Buylla A, Buskirk DR, Nottebohm F (1987) Monoclonal antibody reveals radial glia in adult avian brain. J Comp Neurol 264:159-170.

Alvarez-Buylla A, Theelen M, Nottebohm F (1988) Mapping of radial glia and of a new cell type in adult canary brain. J Neurosci 8:2707-2712.

Anderton BH, Breinburg D, Downes MJ, Green PJ, Tomlinson BE, Ulrich J, Wood JN, Kahn J (1982) Monoclonal antibodies show that neurofibrillary tangles and neurofilaments share antigenic determinants. Nature 298:84-86.

Baier H, Klostermann S (1994) Axon guidance and growth cone collapse in vitro. Neuroprotocols: a companion to methods. Neuroscience 4:96-105.

Bignami A, Dahl D (1989) Vimentin-GFAP transition in primary dissociated cultures of rat embryo spinal cord. Int J Dev Neurosci 7:343-357.

Campenot RB (1977) Local control of neurite development by nerve growth factor. Proc Natl Acad Sci USA 74:4516-4519.

Chang S, Rathjen FG, Raper JA (1990) Neurite outgrowth promoting activity of $\mathrm{G} 4$ and its inhibition by monoclonal antibodies. J Neurosci Res 25:180-186.

Cheng HJ, Nakamoto M, Bergemann AD, Flanagan JG (1995) Complementary gradients in expression and binding of ELF-1 and Mek4 in development of the topographic retinotectal projection map. Cell 82:371-381.

Constantine-Paton M, Cline HT, Debski E (1990) Patterned activity, synaptic convergence, and the NMDA receptor in developing visual pathways. Annu Rev Neurosci 13:129-154.

Crossland WJ, Cowan WM, Rogers LA, Kelly JP (1974) The specification of the retino-tectal projection in the chick. J Comp Neurol 155:127-164.

Crossland WJ, Cowan WM, Rogers LA (1975) Studies on the development of the chick optic tectum. IV. An autoradiographic study of the development of retino-tectal connections. Brain Res 91:1-23.

Dahl D (1981) The vimentin-GFA protein transition in rat neuroglia cytoskeleton occurs at the time of myelination. J Neurosci Res 6:741-748.

Dahl D, Rueger DC, Bignami A, Weber K, Osborn M (1981) Vimentin, the 57,000 molecular weight protein of fibroblast filaments, is the major cytoskeletal component in immature glia. Eur J Cell Biol 24:191-196.

Davenport RW, Thies E, Nelson PG (1996) Cellular localization of guidance cues in the establishment of retinotectal topography. J Neurosci 16:2074-2085.

Donoghue MJ, Lewis RM, Merlie JP, Sanes JR (1996) The Eph kinase ligand AL-1 is expressed by rostral muscles and inhibits outgrowth from caudal neurons. Mol Cell Neurosci 8:185-198.

Drescher U, Kremoser C, Handwerker C, Löschinger J, Noda M, Bonhoeffer F (1995) In vitro guidance of retinal ganglion cell axons by RAGS, a $25 \mathrm{kDa}$ tectal protein related to ligands for Eph receptor tyrosine kinases. Cell 82:359-370.

Edwards MA, Caviness Jr VS, Schneider GE (1986a) Development of cell and fiber lamination in the mouse superior colliculus. J Comp Neurol 148:395-409.

Edwards MA, Schneider GE, Caviness Jr VS (1986b) Development of the crossed retinocollicular projection in the mouse. J Comp Neurol 148:410-421.

Fields RD, Neale EA, Nelson PG (1990) Effects of patterned electrical activity on neurite outgrowth from mouse sensory neurons. J Neurosci 10:2950-2964.

Flanagan JG, Leder P (1990) The kit ligand: a cell surface molecule altered in steel mutant fibroblasts. Cell 63:185-194.

Fraser SE (1992) Patterning of retinotectal connections in the vertebrate visual system. Curr Opin Neurobiol 2:83-87.

Fraser SE, Hunt RK (1980) Retinotectal specificity: models and experiments in search of a mapping function. Annu Rev Neurosci 3:319-352.

Frost DO, Edwards MA, Sachs GM, Caviness VJ (1986) Retinotectal projection in reeler mutant mice: relationships among axon trajectories, arborization patterns, and cytoarchitecture. Brain Res 393:109-120.

Gao P-P, Zhang J-H, Yodoyama M, Racey B, Dreyfus CF, Black IB, Zhou R (1996) Regulation of topographic projection in the brain: Elf-1 in the hippocamposeptal system. Proc Natl Acad Sci USA 93:11161-11166.

Giloh H, Sedat JW (1982) Fluorescence microscopy: reduced photo- 
bleaching of rhodamine and fluorescein protein conjugates by $N$-propyl gallate. Science 217:1252-1255.

Godement P, Bonhoeffer F (1989) Cross-species recognition of tectal cues by retinal fibers in vitro. Development 106:313-320.

Godement P, Salaün J, Imbert M (1984) Prenatal and postnatal development of retinogeniculate and retinocollicular projections in the mouse. J Comp Neurol 230:552-575.

Halfter W, Newgreen DF, Sauter J, Schwarz U (1983) Oriented axon outgrowth from avian embryonic retinae in culture. Dev Biol 95:56-64

Johnston AR, Gooday DJ (1991) Xenopus temporal retinal neurites collapse on contact with glial cells from caudal tectum in vitro. Development 113:409-417.

Kenimer JG, Habig WH, Hardegree MC (1983) Monoclonal antibodies as probes of tetanus toxin structure and function. Infect Immun 42:942-948.

Klostermann S, Bonhoeffer F (1996) Investigations of signaling pathways in axon growth and guidance. Perspect Dev Neurobiol 4:237-252.

Kozlosky CJ, VandenBos T, Park L, Cerretti DP, Carpenter MK (1997) LERK-7: a ligand of the Eph-related kinases is developmentally regulated in the brain. Cytokine 9:540-549.

Lemmon V, McLoon SC (1986) The appearance of an L1-like molecule in the chick primary visual pathway. J Neurosci 6:2987-2994.

Lemmon V, Rieser G (1983) The development distribution of vimentin in the chick retina. Brain Res 313:191-197.

Lillian L (1996) Changes in retinal cell fate induced by overexpression of EGF receptor. Nature 377:158-162.

Lund RD, Bunt AH (1976) Prenatal development of central optic pathways in albino rats. J Comp Neurol 165:247-264.

Marcus RC, Mason CA (1995) The first retinal axon growth in the mouse optic chiasm: axon patterning and the cellular environment. J Neurosci 15:6389-6402.

Marcus RC, Blazeski R, Godement P, Mason CA (1995) Retinal axon divergence in the optic chiasm: uncrossed axons diverge from crossed axons within a midline glial specialization. J Neurosci 15:3716-3729.

Mey J, Thanos S (1992) Development of the visual system of the chick-a review. J Hirnforsch 33:673-702.

Misson JP, Edwards MA, Yamamoto M, Caviness VJ (1988) Identification of radial glial cells within the developing murine central nervous system: studies based upon a new immunohistochemical marker. Brain Res Dev Brain Res 44:95-108.

Misson JP, Austin CP, Takahashi T, Cepko CL, Caviness VJ (1991) The alignment of migrating neural cells in relation to the murine neopallial radial glial fiber system. Cereb Cortex 1:221-229.

Monschau B, Kremoser C, Ohta K, Tanaka H, Kaneko T, Yamada T, Handwerker C, Hornberger MR, Löschinger J, Pasquale EB, Siever DA, Verderame MF, Müller B, Bonhoeffer F, Drescher U (1997) Shared and distinct functions of RAGS and ELF-1 in guiding retinal axons. EMBO J 16:1258-1267.

Nakamoto M, Cheng H-J, Friedman GC, McLaughlin T, Hansen MJ, Yoon CH, O'Leary DDM, Flanagan JG (1996) Topographically specific effects of ELF-1 on retinal axon guidance in vitro and retinal axon mapping in vivo. Cell 86:755-766.
Roskies AL, O’Leary DD (1994) Control of topographic retinal axon branching by inhibitory membrane-bound molecules. Science 265: 799-803.

Roskies AL, Friedman GC, O'Leary DD (1995) Mechanisms and molecules controlling the development of retinal maps. Perspect Dev Neurobiol 3:63-75.

Sachs GM, Schneider GE (1984) The morphology of optic tract axons arborizing in the superior colliculus of the hamster. J Comp Neurol 230:155-167.

Sambrook J, Fritsch EF, Maniatis T (1989) Molecular cloning: a laboratory manual, 2nd Ed, p 7.51. Plainview, NY: Cold Spring Harbor Laboratory.

Simon DK, O'Leary DD (1990) Limited topographic specificity in the targeting and branching of mammalian retinal axons. Dev Biol 137:125-134.

Simon DK, O'Leary DD (1991) Relationship of retinotopic ordering of axons in the optic pathway to the formation of visual maps in central targets. J Comp Neurol 307:393-404.

Simon DK, O'Leary DD (1992) Responses of retinal axons in vivo and in vitro to position-encoding molecules in the embryonic superior colliculus. Neuron 9:977-989.

Stahl B, von Boxberg Y, Müller B, Walter J, Schwarz U, Bonhoeffer F (1990) Directional cues for retinal axons. Cold Spring Harb Symp Quant Biol 55:351-357.

Stein BE (1984) Development of the superior colliculus. Annu Rev Neurosci 7:95-125.

Stirling RV (1991) Molecules, maps, and gradients in the retinotectal projection. Trends Neurosci 14:509-512.

Takahashi T, Misson JP, Caviness VJ (1990) Glial process elongation and branching in the developing murine neocortex: a qualitative and quantitative immunohistochemical analysis. J Comp Neurol 302:15-28.

Tessier-Lavigne M, Goodman CS (1996) The molecular biology of axon guidance. Science 274:1123-1133.

Udin SB, Fawcett JW (1988) Formation of topographic maps. Annu Rev Neurosci 11:289-327.

Vanegas H (1984) Comparative neurology of the optic tectum, p 850. New York: Plenum.

Vanselow J, Thanos S, Godement P, Henke FS, Bonhoeffer F (1989) Spatial arrangement of radial glia and ingrowing retinal axons in the chick optic tectum during development. Brain Res Dev Brain Res 45:15-27.

Wizenmann A, Thies E, Klostermann S, Bonhoeffer F, Bahr M (1993) Appearance of target-specific guidance information for regenerating axons after CNS lesions. Neuron 11:975-983.

Wood JN, Anderson BH (1981) Monoclonal antibodies to mammalian neurofilaments. Biosci Rep 1:263-268.

Zhang J-H, Cerretti DP, Yu T, Flanagan JG, Zhou R (1996) Detection of ligands in regions anatomically connected to neurons expressing the Eph receptor BSK: potential roles in neuron-target interaction. J Neurosci 16:7182-7190. 